\title{
Transforming Nigeria's Agricultural Value Chain
}

\author{
Usman Philemon Gidanmana
}

\begin{abstract}
Agriculture has the potential to transform the economic indices in Nigeria to a positive one and shore up the country's earnings. To be sure, agriculture was the backbone of Nigeria's economy before crude oil was discovered in the early 1970s. In the first decade since independence in 1960, the agriculture sector accounted for an average of $57 \%$ of GDP (CBN, 2008) and generated $64.5 \%$ of the country's export earnings (Verter \& Becvarova, 2016). However, from 1970 to late 2000s, agriculture sector's contribution to GDP and export earnings had steadily plummeted, since Nigeria's focus shifted to oil exploration. From 2012, the sector has contributed an average of $23.5 \%$ to GDP and generated a meager $5.1 \%$ of export earnings (NBS, 2016). The recent fall in crude oil prices and corresponding rise in agriculture products prices (barrel of crude oil @US\$55.83 and barrel of palm oil @US\$95) has triggered serious conversations on the critical role agriculture has to play in diversifying the economy. "Agriculture is the new oil" is one sentence that has been reverberating around the country since 2011. Two key determinants of growth in agriculture are: increase in yield per hectare and land expansion. While land expansion has thrived and driven growth in agriculture in Nigeria, yield per hectare has been low because of poor and limited farming inputs such as seedlings, pesticides and fertilizers. Processing and marketing activities have been
\end{abstract} plagued by poor infrastructure, low investment and unfavorable government policies. This paper argues that the country's agriculture sector is in urgent need of massive investments that will upgrade the production and processing segments, and stimulate value addition across most critical segments of the value chain. To analyze Nigeria's agricultural value chain, this paper focuses on cocoa and dairy as case studies. The author makes a strong case for the upgrade of the production and processing segments of the value chain. FAO opines that an increase in supply of improved seedlings, pesticides and fertilizers can significantly increase Nigeria's production scope for cocoa by $\mathbf{7 0 \%}$ which is presently at $\mathbf{2 4 8 , 0 0 0}$ tonnes per annum. Introducing appropriate tariff on cocoa beans will not only stifle its sale by opportunistic merchants who offer a higher premium than processors, but has significant scope for raising the percentage of processed cocoa from its current $30 \%$. This way, the country can upgrade processing in the cocoa value chain, create jobs and generate higher income for processed cocoa, up from the 2014 level of US\$144m. Dairy is a major import for Nigeria and accounted for $6 \%$ of total food import in 2016. With a consumption rate of 1.7 million tonnes per annum, Nigeria produces only 0.6 million tonnes per annum, which necessitates the spending of an average of US $\$ 480 \mathrm{~m}$ on imports annually to close the production deficit. This paper has identified production as a key upgrade segment in the dairy value chain and recommends breed improvement as strategy to beef up dairy production. It also recommends the establishment of suitable grazing reserves, milk collection centers, provision of extension services, improved access to pasture and water to enhance dairy production. Lastly, the author recommends stronger integration between pastoralists and processors as this will promote import substitution and stimulate production.

Index Terms - Agriculture sector, Agricultural value chain, input supply, production, processing, marketing, trade, seedlings, pesticides, fertilizers, cocoa, dairy, breeding.

\section{INTRODUCTION}

In the 1960s, before it turned its attention to oil, Nigeria was among the most promising agricultural producers in the world. From 1962 to 1969, export crops were the country's main foreign exchange earner. The agriculture sector accounted for an average of $57 \%$ of Nigeria's GDP, and generated about $64.5 \%$ of its export earnings. Nigeria was the major global exporter of palm oil, ahead of Malaysia and Indonesia; and responsible for $47 \%$ of global groundnuts exports, ahead of the US and Argentina (Green 2013). We have witnessed steady reversal of fortunes, with Nigeria now becoming the largest importer of tomatoes, after being responsible for $65 \%$ of the tomatoes consumed in the West African sub-region. Also, after being the second world exporter of cocoa, responsible for $18 \%$ of global export, this figure has since dropped to $8 \%$, making Nigeria only the sixth global exporter of cocoa beans. Agriculture sector contribution to GDP and export earnings have steadily plummeted from 1970 due to Nigeria's shift of focus from agriculture to oil exploration. This shift marked the beginning of the country's deteriorating performance in agriculture and left Nigeria the poorer in terms of economic growth and sustainable development. Whereas the agriculture sector is broad and has the potential to engage our teeming populace towards engineering robust growth of the economy, the oil and gas jobs account for less than $1 \%$ of total employment. In his article, Green (2013) expressed regret at the realization that successive Nigerian governments could not find a productive link between the two sectors to create the synergy that will drive growth. Instead, the governments, especially between the 1970s and 1980s came up with restrictive trade policies such as tariff increases, rise in import licenses and duties, export bans and tariffs, and centralization of the marketing of agricultural produce through the formation of crop-specific commodity boards which gave birth to an inefficient private sector, and opened up different avenues for corruption to thrive in the public sector. In his own words, Mr. Adesina Akinwumi (the then Minister of Agriculture) said "it just makes absolutely no sense...at all" that Nigeria has transitioned from being a self sufficient country in food to being a net importer, spending US $\$ 11 \mathrm{bn}$ on imports of rice, fish and sugar annually (Adesina, 2013). He did promise to fix the problem. But then, not everything is in the minister's hands, when climate change poses a threat to Nigerian agriculture, with the World Bank predicting a drop of up to 
$30 \%$ in Nigeria's crop output due to erratic rainfall and higher temperatures. The minister admitted that the African continent has enormous potential for agricultural growth, yet remains a continent where food insecurity and malnutrition are widespread and persistent. A paradox amidst palpable optimism.

A report prepared by ' $P w C^{\prime}$ (2017) argues that agriculture is Nigeria's single largest economic sector. However, the country's agricultural value chain is highly underdeveloped with focus being more on production rather than on enhancing value addition across all four value chain segments of production, input supply, processing, and marketing and trade. Available statistics show that in 2016, agriculture accounted for $24.4 \%$ of the GDP, but its impact on government and export revenues accounted for a meager $4.8 \%$ of total foreign earnings. This is nothing compared to Brazil which tenaciously improved its agricultural value chain with great benefits to show for it. Its agribusiness generated 16 million jobs in 2012 and its agricultural exports accounted for $46.3 \%$ of total exports in 2016. Today, Brazil is a global producer of several agro processed commodities such as orange juice, sugar and ethanol. This is owing to improved seeds, improvement in soil fertility, increased adaptation to technology, and the support of domestic and international institutions.

Although Nigeria is a big producer of many agriculture commodities, its self-sufficiency can only be guaranteed by way of deepening diversification, increased production, value addition across its agric food products, and developing its agriculture value chain (Adesina, 2015).

\section{METHODOLOGY}

\section{Approach Used}

This article takes a look at Nigeria's agricultural value chain using cocoa and dairy as case studies. It recommends ways of upgrading key segments of the value chain, based on prevailing practices used by agro-processing economies and leading agriculture producers. Conclusions arrived at were based on primary and secondary research, which comprised a blend of desktop research, telephone conversations and face-to-face interviews. Qualitative and quantitative data were generated and analyzed, and outcomes are presented in the article. Respondents were largely farmers, processors and industry experts in the cocoa and dairy industries in south west and northern Nigeria respectively.

\section{Data Limitations}

This article is limited by unavailability of data from some industry (at the time of research) such as data on production, yield, consumption, exports and imports. However, data gaps were estimated using assumptions that are clearly stated herein. Information used are not exhaustive and are essentially products of insights from interviews conducted which have not been independently verified. For currency conversions, the assumed exchange rate is the official exchange rate obtained from the corresponding Central Banks. Key crops from Nigeria's major products, top exports and top imports, were selected for analysis of the sector based on government's substitution plans.

\section{REVIEW OF NIGERIA'S AGRICULTURE SECTOR}

Use of poor inputs led to declining yields across key crops Growth in yield per hectare and land expansion are the basis of agriculture growth (Fugile and Rada, 2013). This growth can be achieved by increasing inputs as well as by improving productivity through the use of technology. In the last four decades, the yield of most key crops such as cassava, wheat and cocoa beans, has steadily declined - a result of low utilization of improved seedlings and agrochemicals, and poor adoption of technology. On the other hand, the yield of rice increased steadily owing to government's increased support for rice production through subsidized agrochemicals and credit facilities from various intervention funds.

In sharp contrast to agriculture yield, agricultural land usage in Nigeria increased across key crops such as cassava, cocoa beans, wheat and rice paddy. Driven primarily by the increase in number of persons involved in farming. FAO (2017) opines that, in the long run, it is expected that the use of technology and better inputs will play an increasing role in raising agriculture productivity and reducing growth of agriculture land usage.

The share of global production of key crops remains low

Nigeria's share of the global production, for most key crops, has remained low over the past four decades. Its global production for ground nuts, cocoa and oil palm declined because of slow adoption of efficient production processes. Production remained at subsistence level due to a combination of rural poverty, rising rural-urban migration and land degradation. Nigeria's yield in ground nut, cassava, cocoa beans and oil palm remained low in comparison to other countries. For example, in 2014, the yield of these crops were lower than the global average yield of all producing countries. This suggests that the other countries, in contrast to Nigeria, utilized improved inputs and technology to increase their yield and production levels.

\section{Increasing food consumption driven by population}

According to FAO Statistics (2017) Nigeria's share of global food consumption averaged 3.4\% - highest among African countries. Nigeria's population is projected to rise to $400 \mathrm{~m}$ by 2050 , making it the third most populous country in the world. Its food consumption rate is projected to rise by $4 \%$ per annum. This points to the need to increase production to match its food demand and achieve self-sufficiency. In their examination of the rural and urban food consumption in Nigeria, Obayelu et al (2018) found that the urban populace consume more processed food than the rural population. FAO (2017) believes the increasing rural-urban migration will trigger an increase in the consumption of agro-processed products.

Low production of agric products promotes import dependency

Across most, if not all key crops in Nigeria, the rate of consumption far outstrips production. The country depends largely on imports to bridge the deficit, making it a net importer since 1975. Between 2011 and 2015, Nigeria spent N1.4 trillion on food imports including rice, sugar, wheat, milk and malt extract. This development makes Nigeria vulnerable to changes in the global agro-commodity prices, with direct impact on inflation and foreign reserves. 
Decline in production and quality have caused decline in agro-processed exports

Agro-processed exports declined by $41 \%$ to N143bn between 2011 and 2015. This accounted for only 20\% of non-oil exports in 2015, mainly leather and processed skin, cocoa derivatives and cocoa, alcoholic and non-alcoholic beverages. Decline in the production of agric and agro-processed commodities like ground nut, cotton, cocoa and palm oil caused Nigeria the loss of US\$10bn in annual exports. The Nigerian Export Promotion Council (NEPC) attributed this decline in food exports to non-compliance with regulatory and documentation requirements for food imports to the European Union and United Kingdom. The World Bank estimates that Nigeria may have lost US\$6.9bn in 2015 resulting from rejected food exports.

\section{THE AGRICULTURAL VALUE CHAIN}

Nigeria's Agricultural Value Chain

Agriculture Sector Challenges

\begin{tabular}{|c|c|c|c|}
\hline Input Supply & Production & Processing & Marketing/Trade \\
\hline $\begin{array}{l}\text { Poor accessibility to } \\
\text { improved seedlings }\end{array}$ & $\begin{array}{l}\text { Frequent pest and disease } \\
\text { attack }\end{array}$ & $\begin{array}{l}\text { High cost of power } \\
\text { generation }\end{array}$ & Illegal food imports \\
\hline $\begin{array}{ll}\text { High cost of } \\
\text { agrochemicals }\end{array}$ & Poor irrigation systems & $\begin{array}{l}\text { High cost of processing } \\
\text { equipment }\end{array}$ & Poor road network \\
\hline $\begin{array}{l}\text { Difficulty in acquiring } \\
\text { land }\end{array}$ & $\begin{array}{l}\text { Low utilization } \\
\text { mechanized tools }\end{array}$ & Limited storage facilities & $\begin{array}{l}\text { Low cost of imported } \\
\text { agricultural products }\end{array}$ \\
\hline $\begin{array}{l}\text { Climatic variation - high } \\
\text { temperature and irregular } \\
\text { rainfall }\end{array}$ & Inadequate research & $\begin{array}{l}\text { Inadequate } \\
\text { personnel }\end{array}$ & $\begin{array}{l}\text { Inadequate market } \\
\text { information }\end{array}$ \\
\hline
\end{tabular}

\section{Regulators:}

Federal Ministry of Agriculture \& Rural development (FMARD)

Standard Organization of Nigeria (SON)

National Agency for Food, Drug Administration and Control (NAFDAC)

\section{Finance Institutions:}

Central Bank of Nigeria (CBN)

Development Finance Institutions - Bank of Agriculture (BOA), Bank of Industry (BOI)

Nigeria Sovereign Investment Authority (NSIA)

Commercial Banks

Private Equity Firms

\section{Research Institutes}

Domestic research institutes - National Agricultural Research System, Research Institutes across crops.

International research institutes - International Agricultural Research Centre (IARC) and the International Institute of Tropical Agriculture.

The challenges can be summarized as: Poor infrastructure, Low extension services, Inadequate skilled personnel, Inadequate research, Low funding, Weak institutions and Limited storage facilities.

\section{REVIEW OF CHALLENGES \& RECENT REFORMS ALONG THE AGRICULTURE VALUE CHAIN IN NIGERIA}

\section{Input Supply}

Over time, agricultural production in Nigeria has been hampered by limited availability of inputs. Local farmers lack the required seedlings, fertilizer and water that will support production activities. And the process of securing land apart from being expensive, is bedeviled by red-tapism which discourages agricultural activities. The Agricultural Transformation Agenda introduced in 2010 by government was tailored to address this challenge. From 2011 to 2014 government policies facilitated the supply of subsidized fertilizers and seedlings to about 14million farmers (about $18 \%$ of Nigerian farmers). Additionally, some state governments introduced different initiatives to ease the process of land acquisition and issue of Certificates of Occupancy for agric purposes. In particular, Edo State government subsidized land acquisition costs and eased Certificate of Occupancy acquisition, while Anambra state government promoted community relations to ease land acquisition process and enacted the Land Acquisition Law to smoothen land transfers.

\section{Production}

Water and Irrigation Systems: are challenged by low investment in irrigation systems and water pollution, and increasing deforestation which have combined to impact the quality and availability of water for agricultural production. To address this, several irrigation projects such as the Zauro irrigation project and Ogun irrigation project, among others, have been initiated. While the Zauro project was aimed at facilitating the production of 42,000 tons of rice, 4,800 tons of maize, 2200 tons of cowpea and 800 tons of wheat annually, the Ogun project is expected to develop 12,000 hectare of land for irrigation purposes. Both projects have dragged on for years and have yet to be completed.

Mechanization: The quality of agricultural products is greatly hampered by the slow adoption of mechanization in Nigeria. This reluctance is due to limited accessibility to modern agriculture equipment as well as limited availability of skilled workers.

\section{Storage}

Nigerian farmers have grappled with high post-harvest losses, low food quality and undersupply of agricultural products owing to limited storage facilities. To cut these losses, the government, in 2014, partnered with Africa Exchange (AFEX) to introduce the Electronic Warehouse Receipt System (e-WRS) to facilitate the storage of 
agricultural products. This initiative made certified warehouses available for farmers and distributors to store their farm products which curbed post-harvest losses. Moreover, warehouse receipts given to them serves as eligible collateral for the farmers to access finance from banks. By 2016, the scheme had engaged 60,000 farmers across eight states with plans to build more warehouses to reach more farmers.

\section{Processing}

To further reduce post-harvest losses, it is essential to process agricultural products. In Nigeria, processing is within the ranges of $35 \%-50 \%$ for fruits and vegetables and $15 \%-25 \%$ for grains. However, inadequate extension services for post-handling, poor quality control and limited use of modern processing practices and technology have combined to limit the processing of agricultural output. To check this, government introduced the Staple Crops Processing Zone (SCPZ) Programme to develop commercial agriculture, increase value addition and reduce the country's dependence on food imports. The Federal Ministry of Agriculture and Rural Development (FMARD) estimates that the first 12 SCPZ sites would boost annual farming production by 12.7 million metric tons, agric processing production by 6.2 million metric tons, and create about 550,000 direct jobs.

\section{Marketing and Trade}

In a study conducted by Tunde and Adeniyi (2012) in Kwara State, the authors found that the high cost of transportation, bad roads, and long distances from the farms to the market negatively impact the marketing of agricultural produce. In most other states, the challenges associated with farm-to-market are basically poor road networks, poor logistics infrastructure, and inadequate market information to leverage local and external opportunities.

From trade perspective, limited grasp of key export markets such as US, EU and UK, and low quality of agricultural products have stifled international trade. To advance trade efficiency along the Lagos-Kano-Jibiya (LAKAJI) corridor, the USAID initiated the Nigeria Expanded Trade and Transport (NEXTT) project in 2012. By 2015 , the project facilitated a $25 \%$ reduction in time for importing goods and 5\% decrease in time for exporting goods through Lagos to Jibiya border. In another study, Carana Corporation (2017) reported a 35\% decrease in cost-to-import, and $21 \%$ reduction in cost-to-export for goods passing through the LAKAJI corridor.

\section{Research}

Improvements in agriculture products including rice, cassava, beans, sorghum, and livestock has been recorded owing to support enjoyed from domestic and international research institutes. For instance, International Institute of Tropical Agriculture (IITA) and its partners introduced and supported more than 40 cassava varieties from 2002 - 2010 which contributed significantly to the growth of the cassava industry. The National Animal Production Research Institute (NAPRI), on its part, utilized crossbreeding to upgrade some indigenous cattle to produce higher milk yield. However, inadequate funding, poor research infrastructure, unskilled workers and weak linkages to the agric sector are factors that limited the impact of support provided by some domestic research institutes.

In sharp contrast, the commitment to spend $1 \%$ of their GDP on research is, perhaps, the reason Brazil is succeeding, because it is able to attract the best minds and hands to drive development in agriculture. This initiative has boosted agricultural production by more than $300 \%$ in the last four decades. Taking a cue from this, the Nigerian government plans to improve the contribution of domestic research institutions by providing funds to the National Agricultural Research System (NARS) to attract talent and expertise and promote domestic and foreign partnerships.

\section{Financing}

Long-term and affordable financing across the value chain segments is a prerequisite to developing the agricultural sectors. Through the years, government promoted several financing interventions in the agricultural sector. But the sustainability of the different intervention schemes and accessibility by farmers continues to constitute a major constraint to expanding credit growth in the sector. Consequently, in 2015, the Central Bank of Nigeria in collaboration with other financial institutions i.e. commercial banks, microfinance banks and development finance institutions introduced the CBN's Anchor Borrower Programme with a target to spend N40bn by March 2017. The Programme was able to disburse N33.3bn to 146,557 farmers across 21 states of the federation as at April 2017 (Premium Times, 2017).

\section{Regulators}

Regulators have the task of formulating and enforcing regulations to maintain the quality of agricultural output across the agric value chain. Federal Ministry of Agriculture and Rural Development (FMARD) is the main body saddled with the job of ensuring sustainable access, availability and affordability of quality food. Supporting regulators include Standard Organization of Nigeria (SON), National Agency for Food Drug Administration and Control (NAFDAC) and Federal Produce Inspection Service (FPIS). They are all responsible for ensuring standards for the production and exports of food and agricultural products. But inadequate funding and limited manpower have been serious constraints to success.

\section{STRATEGIES FOR UPGRADE}

\section{A.COCOA}

\section{Production}

Efficient distribution of improved inputs: Quality inputs such as seedlings and agrochemicals are key drivers to improved yield. Although the Cocoa Research Institute of Nigeria (CRIN) has developed many improved cocoa seedlings which are early bearing, high yielding, resistant to pests and diseases, and of good quality, poor accessibility has continued to limit their use in Nigeria. A partnership by government with cocoa cooperatives may boost distribution that could improve inputs. Increased use of pesticides and improved seedlings could increase production by $70 \%$, in line with the industry's experience between 2004 to 2011.

\section{Marketing and Trade}

Proper certification of cocoa beans from farmers and processors by recognized outfits such as UTZ and Rain Forest 
Alliance could help improve the quality and yield of cocoa beans, which will in turn increase productivity and guarantee farmers a fair price for their produce.

\section{Processing}

Introducing export tariff on unprocessed cocoa beans could discourage exports and shift more of it to the processing segment, reduce the ongoing price war between merchants and processors, and increase the quality of cocoa beans available for processing. This is expected to attract more investment to the processing segment as well as optimize the revenue potential across the entire value chain. The case study of Indonesia shown below is a case in point worthy of emulation.

\section{CASE STUDY (Indonesia)}

The introduction of an export tax of between $0-15 \%$ on cocoa beans in Indonesia, targeted at encouraging the processing of cocoa and exportation of cocoa derivatives i.e. powder, butter and paste, facilitated a shift from exportation of cocoa beans to processing which stimulated an increase in processing activities. This policy not only tripled export of cocoa derivatives from below 100,000 tons in 2009 to 274,018 tons in 2015, but also jerked up the volume of trade on cocoa derivatives which raked in export revenues of US\$1.2bn in 2015 as against the paltry US\$326.0m of accrued revenue in 2009. This initiative not only discouraged export of cocoa beans by opportunistic merchants, it boosted processing and exportation cocoa derivatives, facilitated job creation through the reopening of shut processing plants and quadrupled revenues into government coffers.

\section{B.DAIRY}

\section{Production}

Breed Improvement: Improvement in milk production known for low genetic yield requires breed improvement either through natural breeding or artificial insemination. For Nigerian dairy sector, artificial insemination is recommended because most imported cattle do not thrive in our clime which limits the use of natural breeding. Besides, breed improvement is time consuming and could take as long as 10 years to yield desired results. The Turkey example which combined the advantages of imported and local breeds and the provision of long term loans at zero interest to farmers for cattle breeding in addition to the provision of subsidy for the purchase of cattle and breeding equipment could help spike the Nigerian dairy sector.

Increasing dairy extension services: Training traditional producers on animal health and hygiene is an aspect of extension services that can help improve milk quality. Government needs to scale up the extension services it provides by partnering the private sector towards the provision of transportation, logistics and adequate power supply.

Revamp Producer Groups: Inaccessibility to the pastoralists by commercial processors has been a major challenge. Establishing cooperatives and producer groups will not only improve accessibility to the pastoralists, but will foster mutual engagement that could increase the processing of domestic milk. The cooperatives, when established, will facilitate extension services and increase the quality of pastoralists' milk output.

\section{Processing}

Stimulate backward integration: Processors should be encouraged to work closely with pastoralists in order to increase milk supply. A leading processor in Nigeria currently engages pastoralists, provides basic training for them and has set up a milk collection center close to the pastoralists. This initiative is certain to increase local content and support the traditional producers to boost supply.

Upgrade processing tools: Although many local processors have high milk supply owing to proximity to pastoralists, they, however, lack essential processing tools. Essential tools such as homogenizers, blenders, pasteurizers and fillers could boost processing capacity and enhance milk quality. If the local processors can access these tools, it would increase commercial production and reduce milk spoilage.

\section{Marketing and Trade}

Invest in cold chain technology: Until the storage needs of the dairy industry are catered for through developing agric infrastructure, effective marketing and trade will remain essentially limited. Specifically, the installation of cold chain technology in the planned rail construction linking the Northern and Southern Nigeria is a basic requirement that will help ease transport and distribution of quality dairy products across the country.

\section{Retail and consumption}

Whereas local processors of milk still depend on the informal trading method of hawking within the community, commercial processors are deploying the more robust distribution models which include company owned systems, grocery retailing and supermarkets. Several processors are already taking advantage of increasing modern malls by partnering with supermarkets for periodic supply of dairy products. Basically, dairy products come under three categories - powdered, evaporated and condensed milk, packaged in metal cans and sachets of different weights. The price for small sachets range between N30 - N70 and targets consumers who prefer the "trade-down" option. The mid and large sizes enjoy a wide price range of N200 - N7000, depending on the size. Nigeria's milk consumption per capita of 10 litres per person is rated low. However, rising urbanization, increasing retail malls and a rise in per capita income may combine to support higher demand for dairy products.

CASE STUDY (Turkey)

Turkey is one of the top 10 producers of milk in the world today with production at over 16 million tonnes per annum (FAO Statistics, 2017). After realizing the deficiencies in local cattle with milk yield of 0.6-1 ton and weight of $300 \mathrm{~kg}$ compared to high breeds of 3 tons and weight of $500 \mathrm{~kg}$, the country adopted cross breeding (natural and artificial) to improve output. The ultimate goal was to take advantage of early growth ability and higher milk yields of imported breeds to complement the good characteristics of local breeds such as climate adaptation, resistance to disease and parasite, roughage evaluation, high survival rate and reproductive performance abilities.

Government incentives boosted and supported the achievement of desired outcomes. For example, in 2010, the 
Turkish Agricultural Bank provided long term loans at zero interest to farmers for cattle breeding. And through the Ministry of Agriculture and Rural Affairs (MARA) subsidies were made available to support the purchase of cattle and cross breeding equipment. To provide additional boost, the Turkish Cattle Breeders Association, an organization that facilitates the importation of semen for artificial insemination, partnered with dairy farmers and government authorities. By 2016, domestic breed shrank by $44 \%$ to 1.9 million, while crossbreed rose by $3 \%$ to 4.8 million and cultured breed rose by $137 \%$ to 6.6 million. A combination of these measures significantly impacted milk yield which rose by $67 \%$ to $43373 \mathrm{hg}$ per annum and production rose by $92 \%$ to 20.9 million tons.

\section{SUMMARY AND RECOMMENDATIONS}

\begin{tabular}{|c|c|c|}
\hline Programmes & Results & Recommendations \\
\hline $\begin{array}{l}\text { The Nigerian Agricultural Insurance } \\
\text { Corporation (NAIC) was established to } \\
\text { provide insurance cover to farmers, } \\
\text { promote agricultural production, } \\
\text { provide financial support and increase } \\
\text { flow of agricultural credit.. }\end{array}$ & $\begin{array}{l}\text { From } 2007-2010, \text { NAIC insured } \\
\text { about } 35,000 \text { food crops and } 100,000 \\
\text { Ha. commercial crops, representing less } \\
\text { than } 1 \% \text { of Nigeria's food and } \\
\text { commercial crops. } \\
\text { NAIC paid N193m in } 2012 \text { and } \\
\text { N687m in } 2013 \text { as claims to farmers. }\end{array}$ & $\begin{array}{l}\text { Sustainability of this programme is } \\
\text { key to overall success. } \\
\text { More funding aimed at promoting } \\
\text { agricultural production and increasing } \\
\text { flow of agricultural credit is necessary. }\end{array}$ \\
\hline $\begin{array}{l}\text { The Nigeria Incentive-Based Risk } \\
\text { Sharing System for Agricultural } \\
\text { Lending (NIRSAL) was introduced to } \\
\text { provide affordable financing to actors in } \\
\text { the agricultural value chains. } \\
\text { NIRSAL was funded by the CBN to } \\
\text { the tune of US } \$ 500 \mathrm{~m} \text { at inception. }\end{array}$ & $\begin{array}{l}\text { Between } 2011 \text { and 2019, through } \\
\text { Credit Risk Guarantees (CRGs), } \\
\text { NIRSAL has guaranteed } 697 \\
\text { agribusiness loans worth US } \$ 505.9 \mathrm{~m} \text {, } \\
\text { paid N1.274bn Interest drawback to } 271 \\
\text { obilgors, and created over } 400,000 \\
\text { direct jobs with N101bn on } 693 \text { agric } \\
\text { projects. } \\
37,399 \text { farmers were insured against } \\
\text { loss of N6.5bn in revenues. }\end{array}$ & $\begin{array}{l}\text { NIRSAL should stay focused on the } \\
\text { good job it is doing. } \\
\text { NIRSAL should aim at creating more } \\
\text { direct jobs in the agriculture sector to } \\
\text { engage Nigeria's unemployed graduates } \\
\text { engaged across the value chains. }\end{array}$ \\
\hline $\begin{array}{l}\text { The Commercial Agriculture Credit } \\
\text { Scheme (CACS) was launched to fast } \\
\text { track development of the agriculture } \\
\text { sector through the provision of single } \\
\text { digit interest rate loans to farmers. }\end{array}$ & $\begin{array}{l}\text { The CBN has disbursed a sum of } \\
\text { N336.4bn for } 420 \text { projects for the } \\
\text { scheme. The sum released during the } \\
\text { period was mainly allocated to farming } \\
\text { which received } 50.9 \% \text {, and the balance } \\
\text { allocated thus: Processing } 36.9 \% \text {, } \\
\text { marketing } 6.6 \% \text {, storage } 2.4 \% \text { and input } \\
\text { supplies } 3.1 \% \text {. }\end{array}$ & $\begin{array}{l}\text { More funding is possible through } \\
\text { meaningful engagement with the private } \\
\text { sector. This will boost number of } \\
\text { agriculture projects and stimulate more } \\
\text { active participation of small, medium } \\
\text { and large scale farmers in the scheme. } \\
\text { The DMO should raise the three-year } \\
\text { bond funding to accommodate more } \\
\text { participants in the three-year rolling } \\
\text { plan. } \\
\text { Create ecosystems for small, medium } \\
\text { and large scale farmers to floursih. }\end{array}$ \\
\hline $\begin{array}{l}\text { Growth and Employment in States } \\
\text { (GEMS) was established primarily to } \\
\text { generate at least 100,000 direct jobs and } \\
\text { increase the non-oil growth in specific } \\
\text { high potential value chain sectors. } \\
\text { The World Bank and the United } \\
\text { Kingdom's Department for International } \\
\text { Development (DFID) supported the } \\
\text { project with US } \$ 160 \mathrm{~m} \text { and GBP 90m } \\
\text { respectively. }\end{array}$ & $\begin{array}{l}\text { Established an online credit } \\
\text { information platform to enable easy } \\
\text { access to information on available loans } \\
\text { across all financial institutions in } \\
\text { Nigeria. }\end{array}$ & $\begin{array}{l}\text { The States haven't demonstrated } \\
\text { sufficient commitment to engage fully } \\
\text { in this scheme. To stimulate interest, the } \\
\text { federal government could enter into } \\
\text { partnership that are mutually agreeable } \\
\text { to them. } \\
\text { States should establish farm } \\
\text { settlements for absorption of the } \\
\text { unemployed youths to provide skilled } \\
\text { training so they can take advantage of } \\
\text { technology which is becoming } \\
\text { increasingly critical. }\end{array}$ \\
\hline The World Bank approved & The fund is being utilized to empower & This is a good initiative, which if \\
\hline
\end{tabular}


US\$200m loan in March 2017 to foster growth in small and medium scale farming. The credit line has a maturity period of $25-30$ years. small and medium scale farmers to tackle basic production and processing challenges. properly applied, would go a long way to stimulate critical growth across the value chain, especially given the maturity period of the loan.

Source: CBN, GEMS, NAIC, NASS Public Account Committee, NIRSAL, World Bank

\section{REFERENCES}

[1] Akinwumi, A. (2013) "Transforming Nigeria's Agriculture." Speech delivered at the Inauguration of the Agriculture and Food Security Center of the Earth Institute of Columbia University, New York, USA on September 10, 2013. Available at: http://agriculture.columbia.edu/events/past-events/inaugural-seminar-t he-nexus-of-agriculture-environment-and-livelihoods/transforming-ni gerias-agriculture/ [Accessed: 27th March 2020].

[2] Akinwumi, A. (2015). "Is Nigeria's Agricultural sector progressing?" Available

https://infomineo.com/is-nigerias-agricultural-sector-progressing/ [Accessed: 27/03/2020].

[3] Carana Corporation (2017) "Sub-Saharan Africa: Nigeria Expanded Trade and Transport (NEXTT)" Available at: https://www.carana.com/projects/subsaharanafrica/824-nigeria-expan ded-trade-and-transport-nextt [Accessed: 20/03/2020]

[4] Cassava Processing Research in Nigeria, IITA Research for Development (R4D) Review http://r4dreview.iita.org/index.php/tag/cassava-research/ [Accessed: 20/03/2020]

[5] CBN Statistical Bulletin (2008), Pwc Analysis https://www.cbn.gov.ng/documents/Statbulletin.asp [Accessed: 20/03/2020]

[6] FAO (2017) "Improving Land Use" http://www.fao.org/3/z5700e/z5700e07.htm [Accessed: 20/03/2020]

[7] FAO (2017) "Nigeria at a Glance" Available at: http://www.fao.org/nigeria/fao-in-nigeria/nigeria-at-a-glance/en/ [Accessed: 20/03/2020]

[8] FAO Statistics PwC Analysis Available at: https://www.pwc.com/ng/en/assets/pdf/transforming-nigeria-s-agric-v alue-chain.pdf [Accessed: 20/03/2020]

[9] Green, A.R. (2013). "Agriculture is the future of Nigeria" - This Is Africa (Of $\quad$ Financial $\quad$ Times) https://www.forbes.com/sites/skollworldforum/2013/08/08/agriculture -is-the-future-of-nigeria/\#7c8bc8626d96

[10] NAIC (2017) "Insurable Risks in the agricultural value chain." Available https://naic.gov.ng/news_inside/insurable-risks-in-the-agricultural-val ue-chain (Accessed: 27/03/2020).

[11] NASS Public Accounts Committee (2020). "NISRAL has transformed Agribusiness." Available at: https://www.thecable.ng/nisral-has-transformed-agribusiness-says-rep s-committee (Accessed: 27/03/2020)

[12] National Bureau of Statistics Foreign Trade Report (2013 \& 2015) http://www.nigerianstat.gov.ng/library, \%20PwC\%20Analysis [Accessed: 20/03/2020]

[13] National Bureau of Statistics (2016) "Q4 GDP Report" Available at: file:///C:/Users/HP\%20USER/Downloads/NBS\%20GDP\%20Q4\%202 016\%20FULL\%20REPORT-min.pdf [Accessed: 20/03/2020]

[14] Obayelu, A. E., Okoruwa, V. O. and O. A, Oni (2018) "Analysis of Rural and Urban households' food consumption differential in the North- Central, Nigeria - A micro-economic approach" International Scholars Journal Vol.6 (3), pp.001-009 March 2018.

[15] Premium Times (2017) "Anchor Borrowers' Programme: Farmers repay N7 billion" Available at https://www.premiumtimesng.com/business/business-news/230352-an chor-borrowers-programme-farmers-repay-n7-billion-cbn.html [Accessed: 20/03/2020]

[16] PwC Report - Understanding the Brazil agribusiness: what are the drivers, the issues and the perspectives (September 2013)

[17] PwC (2017) "Promoting Economic Prosperity: Analysis of the State-Level Business Environment in Nigeria," PwC, Nigeria Federal Republic of Nigeria (2010) "ECOWAP/CAADP Process National Agricultural Investment Plan (NAIP) 2011-2014",

[18] Tunde, A.M. and Adeniyi, E.E (2012) "Impact of road transport on Agricultural Development: A Nigerian Example" Ethiopian Journal of Environmental Studies and Management EJESM, Vol. 5 No. 3, pp.232-238.

[19] Verter, N., and V. Becvarova, (2016) "The Impact of Agricultural Exports on Economic Growth in Nigeria" Available:
file:///C:/Users/HP\%20USER/Downloads/The_Impact_of_Agricultur al_Exports_on_Economic_Gro.pdf [Accessed: 20/03/2020] 